Prof. Elliot Smith, writing before the positive evidence pointing to the recent origin of that specimen was available, argues that the cultural evidence, upon which reliance had been placed in support of the antiquity of the remains, in effect tells against it. In particular, he maintains that the deformation of the teeth exhibited by Oldoway man, a filing away of the anterior surface of the lower incisors, first appears, with other forms of dental deformation, in human remains from a Ptolemaic-Roman cemetery near Dacca, in Lower Nubia, recorded by Dr. D. E. Derry and himself. He suggests, further, that the process of filing was the original device for removing the teeth, and was almost immediately superseded by lateral filing, or the more drastic evulsion. Therefore, he thinks, the practice of dental mutilation was not introduced before about 300 B.C. In this connexion we may direct attention to the recently published account of the fossil man of Asselar (Sahara) by MM. Boule and Vallois (see p. 280), in which the authors interpret the condition of the upper jaw as due to the evulsion of the upper incisors in early life, and refer to a similar condition in the fossil human remains of Afalou-bou-Rhummel (Algeria). The apparent age of the Asselar man at the time of the operation conforms to its generally accepted relation to puberty ceremonial; while the geological and palæontological evidence, if correctly recorded and interpreted, points unquestionably to a Pleistocene dating.

\section{Radio Communication with very Short Waves}

IT is announced in the Times of Aug. 15 that the experiments which are being carried out by Senator Marconi on communication by means of radio waves of very short wave-length have been successful. As communication was established between two places 170 miles apart, and as the wave-length he used was only $57 \mathrm{~cm}$, the result is of great importance. Hitherto it has been considered impracticable to use such short wave-lengths for transmission owing to the curvature of the earth. The experiments prove that the range of communication with very short waves must extend much farther than the visible horizon. Many experiments, including some by Marconi himself, using very short waves, have been made previously in attempts to reach stations beyond the visible horizon, but all proved unsuccessful. The apparatus now used is of low power and is fitted with portable reflectors. In the recent tests, clear communication was established from Rocca di Papa, near Rome, to Cape Figari, in Sardinia. The transmitting apparatus is quite light, and can now be easily transported anywhere. Formerly the apparatus used was very heavy and cumbersome. It will be of great scientific interest to learn the greatest distance over which this new method can be used.

\section{West Indian Hurricane Season}

IN connexion with recent reports that a hurricane has swept along the Gulf coast of the United States, it may be noted that August is the first of the three months into which a very large proportion of West Indian hurricanes is concentrated, and that at least one of these tropical cyclones occurs in that month rather more often than not. Most of the storms that arrive early in the hurricane season sufficientiy far west to cause serious damage in Texas, as has happened in the present instance, enter the mainland moving north-westwards and then northwards along a characteristically curved path, and begin to diminish in intensity on leaving the sea, but a great many of the August storms first appear farther east and pass across or to the east of the Florida peninsula. It is not yet possible to gauge the exact path followed by the recent storm, but Galveston and Freeport and, to a less extent, Houston were all affected by it. The deaths caused by it have apparently not been very numerous, considering the large amount of material damage, a fact which is attributed to the timely evacuation of the coastal lowlands. This suggests that the section of the forecast service of the United States Weather Bureau which issues hurricane warnings for the Gulf region deserves great credit for effective warnings issued in good time to be of practical service.

\section{Laboratory for Freshwater Biological Research on Windermere}

The laboratories of the Fresh Water Biological Association's Station at Wray Castle, Windermere, were opened to public inspection on Aug. 10. A succession of microscopes was used to show the consecutive life stages from the plankton or microscopic plants through equally microscopic insects to the smallest fish. Exhibits, in tanks, of the small fish which feed on these and of the larger fish completed the life series. In addition, there were tanks containing leeches, fly larvæ, fish-like stage of the newt, and so on. The uses of nets and grabs for obtaining samples of life, water, and bottom material were also demonstrated. Diagrams showed the relations between wind direction, shoals, and the quantity of life, and the consequent variation in the number of fish an angler might catch. An ingenious and newly evolved apparatus involving a light-sensitive potassium cell and a two-valve amplifier, used in the evaluation of the light intensity at various depths, was shown. Research in progress was represented by an ingenious apparatus enabling the researcher to discover the variation in velocity with which a tape worm moves against, or with a constant current. The same water was circulated continuously, but owing to the necessity of keeping it untainted by metals it was pumped round by a water-suction pump. In addition there were numerous cultures of fly larvæ, which are being bred in order to discover which flies develop from named larvæ-flies and larvæ having been originally named irrespective of their relationship. The Fresh Water Biological Association is to be congratulated on the excellent arrangement of the laboratory, and on the great enthusiasm of the staff, and-a most encouraging sign- - of the youthful and very keen body of research workers gathered together there.

\section{Dungeness Preservation Fund}

THE promontory of Dungeness is unique on the south-east coast of England as being the last level area of any size remaining in a natural and undisturbed

No. 3277 , VoL. 130] 
state. It is of particular interest for its bird life, notably as the sole British breeding ground of the Kentish plover. Other uncommon birds also nest there, such as the stone eurlew, and there is a large colony of terns. All this may soon be irretrievably lost if a threat of bungalow building along the sea-front cannot be averted. To secure the position, therefore, efforts are being made to raise $£ 9000$ for the purchase of 271 acres as a bird sanctuary and Nature reserve, to be administered either by the National Trust or by the Royal Society for the Protection of Birds. This area, with its half-mile of shore frontage, is the part immediately in danger, and its price is, unfortunately, already that of a building site. Its acquisition, however, would increase the sanctuary value of adjacent land that is already preserved, and would make inaccessible to development a further stretch of coast lying beyond. The area is thus a key position, and the success of the scheme for its security is very greatly to be desired. The treasurer of the fund is Mr. Percival Jackling, Lloyds Bank, Folkestone.

\section{The Grid and the Cost of Electricity}

Is connexion with Sir Archibald Page's speech, a résumé of which was given in NATURE of Aug. 6, p. 212, Col. H. L. Crosthwait, late R.E., writes asking whether the advent of the 'grid' is likely to reduce the price of electricity or not. So far as can be seen at present, it will reduce the price to numerous consumers. The large stations recently built are generating electricity with far greater economy than the older stations which they replace. The use of the grid will be a great help in securing continuity of supply, and will make it unnecessary to keep a large number of costly machines in reserve in case of breakdowns. The standardisation of the pressures and frequency of supply has cheapened the cost of machines, apparatus, and lamps. We have not heard complaints from any consumer that the electricity companies have been raising the price of electricity; on the contrary, many of them have recently made substantial reductions. It is probable that some consumers will be little affected by the advent of the grid, but many will get their electricity cheaper, and very many dwellers in towns and villages will be able to get electric light and power which they otherwise would not have obtained. The grid is the logical engineering outcome of Ferranti's scheme for lighting London, using electricity at high pressures, first put into operation about forty-four years ago. Its critics have suggested nothing better; as a rule, they desire progress to be made by costly competitive methods. In the future the grid will probably be considerably modified, but at present consumers can look forward to a gradual lowering of the price of electric light and power.

\section{Monument to Otto Lilienthal}

ON Aug. 10 a monument to Otto Lilienthal, the German pioneer of gliding flight, was inaugurated at East Lichterfelde, Berlin, on the mound from which Lilienthal made many of his flights forty years ago. The mound, which was piled up for the purpose by
Lilienthal, is some forty-nine feet high, and a photograph taken some years ago shows its sides covered by shrubs and the top surmounted by a small temple-like construction consisting of pillars supporting a slightly sloping round roof. According to the Times for Aug. 10, the mound has now been cleared of the trees and shrubs, while in the monument at the top, and beneath the central opening in the roof, is a silver globe inscribed with particulars of famous flights. The globe is mounted on a basalt block. A photograph of the inauguration of the memorial appeared in the Times for Aug. 11. Lilienthal was a successful engineer and manufacturer. He was born on May 23, 1848, at Anklam and died on Aug. 10, 1896, at Rhinow through an accident while gliding. Another monument to Lilienthal was inaugurated at Lichterfelde in 1914. This consists of a stone pyramid, bearing on one side a bust and on the summit a figure of a man with outstretched arms supporting a pair of wings.

\section{The Workers' Educational Association and Science}

AT the Annual Conference of the Workers' Educational Association last year, it was resolved "to investigate the possibilities of stimulating further interest in the study of science [that is, natural science] on a non-vocational basis", and the result of the investigation by the Executive Committee has now been circulated. To a scientific worker, it seems in some respects a strange document to be produced in 1932. It says, "The Adult Education Movement cannot afford to neglect scientific thought and knowledge. Ignorance of the influence of science should belong to the past" ; and then, "The study of science, in some of its branches, provided the approach is of the right character, is as attractive and has as great a bearing on social conditions as some of the social sciences". As if the very foundations of social conditions did not rest upon heredity, and health, and the fight against disease, and the production of food, whether from the fisheries or agriculture, and the growing of the raw materials of commerce, and the constant battle against pests, whether they be parasites or plagues, and upon life itself! The Report says, further, "It is only in relation to the question as to how far and in what ways natural science influences and affects society, that our classes can maintain their interest in subjects of this character". It is on strong ground, however, in holding that the teaching of natural science, in so far as it is to be promoted, should avoid the formal lines of a university degree course, and should be of such a character as to attract the uninitiated.

Tre Committee, basing upon its district reports, finds that "there is a lack of interest so far as the adult population is concerned in the study of science ". We think this may be due partly to the ignorance of people as to what natural science means, and partly to the failure to offer suitable courses. But we congratulate the Committee on its unanimous opinion " that the Association should seek to stimulate further interest amongst adult students in the study of science on a non-vocational basis". Towards this end it makes several recommendations, of which the most 